\title{
The Effect of Whole Honey Bee Venom (Apismellifera) on Reducing Skin Infection of Rabbits Caused by Methicillin Resistant Staphylococcus aureus: An In vivo Study
}

\author{
Lamyaa Kadhim Baqer and Raed Taha Yaseen* \\ Department of Microbiology, College of Dentistry, University of Basrah, Basrah, Iraq.
}

\begin{abstract}
The widespread prevalence of bacterial resistance to currently available antibiotics has led to search for nonantibiotic agents to combat infections caused by these bacteria. This study aimed at evaluating the role of whole honey bee venom (WBV) produced by Apismellifera bees in combating rabbit skin infection produced by Methicillin resistant staphylococcus aureus (MRSA). Both in vitro and in vivo testing of susceptibility of MRSA to WBV were tested. In vitro testing showed complete inhibition of MRSA growth by WBV on the agar plate compared to normal saline. For in vivo testing, three different skin regions on the chest and abdomen of six adult laboratory rabbits were inoculated separately by MRSA alone, WBV alone and a combination of both agents. Two macroscopic skin lesions, local swelling and necrosis in the tested regions were inspected and quantitatively scored daily for a total of 5 days. No significant swelling reported in any animal when injecting WBV alone compared to moderate/severe swelling in all 6 animals when using MRSA alone. A combination of WBV/MRSA didn't produce skin swelling too. For local skin necrosis, no necrosis developed in areas inoculated with WBV alone in contrast to its occurrence in 5 / 6 animals inoculated with MRSA alone. With WBV/MRSA combination, 5 animals (83.3\%) showed no necrosis and in remaining one only slight necrosis developed. The study concluded that WBV has a therapeutic potential to combat Staphylococcal skin infection as the majority of tested rabbits didn't develop infection with the use of WBV/MRSA combination.
\end{abstract}

Keywords: Staphylococcus aureus, whole honey bee venom, rabbit.

*Correspondence: raiedtaha@yahoo.com

Raed Taha Alneama, (PhD in Microbiology, Salford University, United Kingdom)

(Received: 01 September 2018; accepted: 14 October 2018)

Citation: Lamyaa Kadhim Baqer and Raed Taha Yaseen, The effect of whole honey bee venom (Apismellifera) on reducing skin infection of rabbits caused by methicillin resistant Staphylococcus aureus: An In vivo study, J Pure Appl Microbiol., 2018; 12(4): 2111-2116. http://dx.doi.org/10.22207/JPAM.12.4.48

(C) The Author(s) 2018. Open Access. This article is distributed under the terms of the Creative Commons Attribution 4.0 International License which permits unrestricted use, sharing, distribution, and reproduction in any medium, provided you give appropriate credit to the original author(s) and the source, provide a link to the Creative Commons license, and indicate if changes were made. 


\section{INTRODUCTION}

The spread of methicillin resistant Staphylococcus aureus (MRSA) across the world becomes a real public health concern over the past 20 years ${ }^{1,2}$. In spite of decreasing mean prevalence of MRSA in Europe the United States and Canada, the situation is different in most countries with still a high rate of MRSA prevalence from $15 \%$ to $45 \%$ 3 .

In Australia, the prevalence showed an increase from $12 \%$ in 2000 to $19 \%$ in $2013{ }^{4}$ while in other regions such as Latin $n$ American countries and India, the prevalence of MRSA is estimated to be $>80 \%$ and $41-80 \%$ respectively ${ }^{3,4}$.

The search for alternative modes of nonantibiotic therapeutic agents to combat these resistant bacteria is agent ongoing all over the world. One of these potential modalities is natural substances extracted from animals and plants with WBV as an example.

The venom of the honey bee is a thick colorless liquid which has a hot-bitter test. It consists of a mixture of protein that produces local inflammation. Honey Bee Venom (Apismellifera) contains anticoagulation factors and increases the blood-clotting time. It is considered to be one of the rich sources for a new component which is used in applicable medicine and biochemistry ${ }^{5}$.

Apitoxin is one of the most important substances that is produced by honey bee. The main composition of whole honey bee venom (WBV) are low molecular polypeptides and enzymes. Peptides such as the mast-cell-degranulating (MCD) peptide, apamin, adolapin and melittin. The enzymes, such as hyaluronidase, phospholipase $\mathrm{A}_{2}\left(\mathrm{PLA}_{2}\right), \alpha$-D-glucosidase, lysopphospholipase, $\alpha$-acetylamino-deosiglucosidase, arylamidase and phosphomonoesterase acid esterase. Moreover, the WBV contains biologically active amines such as histamine and epinephrine and non peptidedrivaties which have different pharmaceutical actions were described by many others ${ }^{6}$. Therapeutic application of anti-arthritis, pain-releasing, and anti-cancer effects of bee venom and its constituent compounds ${ }^{7}$.

Melittin in BV consists about $50 \%$ of the dry weight, it has many potential effects such as antiviral, anti-bacterial and anti-inflammatory action in a different type of cells ${ }^{8,9}$.

$A$ recent study showed that BV has an anti-bacterial action against inflammation of skin diseases $^{10}$.

A study showed the topical application of $\mathrm{BV}$ on the skin can induce cell regeneration process and that will accelerate the healing of the skin $^{11}$.

It was found that innate immune response in the inflammatory skin disease increase in the use of BV, due to the expression of inflammatory gen as a result of the transcription factor NF-kB signalling pathways ${ }^{12}$.

\section{MATERIALS AND METHODS}

\section{Manual collection of bee venom}

The bees were collected from the hive and stored in a small closed glass tube at $-18^{\circ} \mathrm{C}$ to become motionless. The sting apparatus of the insect were removed using the fine tip tweezers under the stereomicroscope. The sac of venom was pressed and the venom collected using a 20$\mu \mathrm{L}$ microcapillary tube ${ }^{13}$. The collected venom was stored at $-18^{\circ} \mathrm{C}$ until it is utilized for further analysis for antibacterial effect.

\section{Bacterial Culture}

Methicillin resistant Staphylococcus aureus was obtained from the microbiology laboratory in AI SADR teaching hospital / Basra often its proper identification and detection utilizing routine laboratory tests and by the Vatic2 system.

\section{In vitro testing of MRSA susceptibility to WBV}

$0.1 \mathrm{ml}$ of a suspension of MRSA was cultured on previously prepared Mueller Hinton agar and incubated at $37^{\circ} \mathrm{C}$ for 24 hours. Two holes were made on the surface of the planted agar using a metal perforator. To the first hole, $0.1 \mathrm{ml}$ of whole Bee venom was added and some volume of normal saline $(0.1 \mathrm{ml})$ was added to the second hole to act as a control and incubated for an overnight. Inhibition zone around venom loaded hole was observed in the next day in contrast to the absence of bacterial growth inhibition around the normal saline hole.

\section{Experimental animals}

The therapeutic application of whole bee venom was tested by using 6 adult rabbit weight from 1200-2000 gram, the rabbit were purchased from the animal market.

The tested area of animals (both side of chest and abdomen) were prepared by clipping the hair using scissor, then the short hair were 
completely removed using hair removal solution. This process was carried out several days before animal inoculated.

The tested area of animals were divided and inoculate into three regions; bacterial inoculation alone, whole bee venom sting alone and both.

The inoculated area was disinfected by using 70\% ethanol (Disinfectol ${ }^{\circledR}, 102$ Chem-Lab NV, Zedelgem, Belgium). After five minutes for ethanol evaporation, a $0.1 \mathrm{ml}$ of saline solution containing $10^{8} \mathrm{cfu}$ of tested bacteria was injected subcutaneously into each region of rabbits by means of a tuberculin syringe and a 22 gauge needle.

The shaved skin of rabbits was stung by a honey bee that collected at the entrance of a hive. The sting was left on the skin for one minute to ensure deliver about $90 \%$ of venom in the sac of honey bee ${ }^{14}$. The immediate sting of the bacterial inoculated area was performed in the tested region of the skin to assess the synergistic effect of the honey bee venoum in the skin.

The macroscopic skin lesions development in the animals were inspected daily using Vernier caliper measurement.

\section{Description of Skin Lesions}

The appearance, the development and the size of an abscess on the rabbit skin were scored since after 24-48 hours of bacterial inoculation, the skin of rabbits showed a significant local reaction.

Two parameters and macroscopic appearance of lesions were recorded for 5 days. The elevated diameter of swelling was scored into negative $(<2 \mathrm{~mm})$, small $(2-5 \mathrm{~mm})$, moderate $(6-10 \mathrm{~mm})$ and severe $(>10 \mathrm{~mm})$.
Secondly, the area of necrosis of the tested regions was divided into negative, slight $(<2 \mathrm{~mm})$, moderate $(2-5 \mathrm{~mm})$ and intensive $(>5 \mathrm{~mm})$ 15 .

\section{RESULTS}

In vitro, the result showed the antimicrobial effect of whole honey bee venom against MRSA. In which, a complete inhibition growth of MRSA occurred.

For macroscopic swelling in the tested area of skin, 2 out of 6 animals showed swelling of less than $2 \mathrm{~mm}$ (i.e. negative) when bee stings alone were used in contrast to the appearance of moderate to severe local swelling

In all MRSA inculcated animals. For those areas inoculated with both MRSA and bee venom, only one out of six animals showed swelling less than $2 \mathrm{~mm}$ (i.e negative ) as shown in table 1 .

The severity of skin necrosis (Table2) showed that no necrosis (except redness of the skin) was recorded in all animals when stung with honey bee alone in contrast to the occurrence of necrosis in five animals that were inoculated with MRSA alone. In these animals, intensive necrosis was recorded in 3 and slight and moderate in one for each.

For those animals inoculated simultaneously with both MRSA and bee venom, no skin necrosis was reported in five animals and in the remaining sixth rabbit, the area of necrosis was less than $2 \mathrm{~mm}$ (i.e. slightly).

The severity of the skin necrosis was also examined in vivo (Table 2). All the animals showed no necrosis (except redness of the skin) when sting with honey bee alone,

Table 1. Appearance of swelling on the skin of the six adult rabbits after stings with honey bee venom and subcutaneous inoculation with MRSA.

\begin{tabular}{llll}
\hline $\begin{array}{l}\text { Size of } \\
\text { swelling }\end{array}$ & $\begin{array}{l}\text { Bee stings } \\
\text { animals }\end{array}$ & $\begin{array}{l}\text { Inoculated animals } \\
\text { with MRSA }\end{array}$ & $\begin{array}{l}\text { Both bees sting animals and } \\
\text { inoculated animals with MRSA }\end{array}$ \\
\hline Nil(negative $)(<2 \mathrm{~mm})$ & 2 & 0 & 1 \\
Small $(2-5 \mathrm{~mm})$ & 0 & 0 & 0 \\
Moderate $(6-10 \mathrm{~mm})$ & 0 & 3 & 0 \\
Sever $(>10 \mathrm{~mm})$ & 0 & 3 & 0 \\
Total of six animals & 2 & 6 & 1 \\
\hline
\end{tabular}


Table 2. Appearance of the necrosis on the skin of six adult rabbits after stings with honey bee venom and subcutaneous inoculation with MRSA.

\begin{tabular}{lccc}
\hline $\begin{array}{l}\text { Degree of } \\
\text { necrosis }\end{array}$ & $\begin{array}{c}\text { Bee stings } \\
\text { animals }\end{array}$ & $\begin{array}{c}\text { Inoculated animals } \\
\text { with MRSA }\end{array}$ & $\begin{array}{c}\text { Both bees sting animals and } \\
\text { inoculated animals with MRSA }\end{array}$ \\
\hline Nil (Negative) & 0 & 0 & 1 \\
Slight $(<2 \mathrm{~mm})$ & 0 & 1 & 0 \\
Moderate $(2-5 \mathrm{~mm})$ & 0 & 1 & 0 \\
Intensive $(>5 \mathrm{~mm})$ & 0 & 3 & 1 \\
Total of six animals & 0 & 5 & 0 \\
\hline
\end{tabular}

\section{DISCUSSION}

In recent years, there is an increase in the use of natural products to act as antimicrobial agents. The rationale for this shift to natural products is increasing in the rates of resistance of bacterial pathogens to the availability of chemotherapeutic agents and antibiotics, in addition to the reduction in the effectiveness of these agents ${ }^{16-20}$.

One of these natural products is honey bee products which had been studied extensively for their potential for a variety of therapeutic applications ${ }^{21-23}$.

Several studies confirmed the usefulness of using bee venom to treat different kinds of ailments such as accelerating wound healing alleviating musculoskeletal and back pain and treatment of angiocardiopathy, arthritis, skin disease and different cancers ${ }^{24,25}$.

Several studies confirmed the antimicrobial activity of venom of honey bee ${ }^{23,26}$ particularly Staphylococcus bacteria such as Staphylococcus mutant ${ }^{21,23,27}$. It is well known that Staphylococcus bacteria are capable of producing skin infection and necrosis that may have profound health negative effect on the patients ${ }^{28,30}$.

In the current study, the effect of whole bee venom was tested on skin infection induced by inoculation of MRSA into rabbit skin. Most of the animals showed no skin infection or necrosis when inoculated simultaneously with both MRSA and by bee venom in contrast to those animals that were inoculated with MRSA alone which showed moderate to severe degrees of skin swelling and necrosis in all. These results confirmed the therapeutic ability of bee venom on curing skin infection produced by Staphylococci.

Melittin is the component in bee venom that was found to act as an antibacterial, anti- inflammatory agent in addition of inhibition of cell growth and apoptosis of many cancer cell line 31-33. Melittin was also found to have an obvious effect that accelerates healing of skin wound and to result in small size scar. A study conducted by Alia et al $^{8}$ in 2013 confirmed that milittin in bee venom had reduced the time of wound healing of skin from eight to five days as well as reducing the size of scar formed on the skin.

In addition to melittin, phospholipase A2 in bee venom is another fundamental compound which was shown to have an antibacterial and anticoagulant effect phospholipase A2 plays as an important role in the generation of chemical mediators, cell proliferation and in the antiinflammatory process ${ }^{34}$.

Many studies showed that melittin possessed a broad spectrum antibiotic effect ${ }^{35-37}$. A study conducted by Choi et al, in $2015^{23}$. Showed that mllittin reduce the presence of bacteria on the wound surface in addition to the acceleration of the rate of healing of the wound. It was found that melittin in bee honey will increase the action of phospholipase A2 against both Gram positive and Gram-negative bacteria ${ }^{38}$.

The antimicrobial effect of melittin against the Gram-positive bacteria, particularly Staphylococcus aureus may be attributed to the fact that it may target the lipid bilayer of the membrane of bacteria ${ }^{39}$.

\section{REFERENCES}

1. Chambers HF, Deleo FR. Waves of resistance: Staphylococcus aureus in the antibiotic era. Nat Rev Microbiol 2009; 7(9): 629-41. pmid:19680247

2. Larsen $A R$, Bocher S, Stegger $M$, Goering R, Pallesen L V, Skov R. Epidemiology of European community-associated methicillin-resistant Staphylococcus aureus clonal complex 80 type IV 
strains isolated in Denmark from 1993 to 2004. J Clin Microbiol 2008; 46: 62-8.

3. World Health Organization (WHO). Antimicrobial resistance: global report on surveillance 2014. WHO: Geneva; 2014.

4. Center for Disease Dynamics, Economics \& Policy (CDDEP). State of the World's Antibiotics, 2015. CDDEP: Washington, D.C.; 2015.

5. Moreno M, Giralt E. Three valuable peptides from bee and wasp venoms for therapeutic and biotechnological use: melittin, apamin and mastoparan were identified. Toxins. 2015; 7(4):1126-1150.

6. Therapeutic application of anti-arthritis, painreleasing, and anti-cancer effects of bee venom and its constituent compounds. Pharmacol Ther. 2007; 115(2):246-70.

7. Lima PR, Brochetto-Braga. Hymenoptera venom review focusing on Apis mellifera. Anim. Toxins Incl Trop Dis.2003; 9(2): 149-162.

8. Alia O, Laila M and Antonious A. Antimicrobial effect of melittin isolated from Syrian honeybee (Apismellifera) venom and its wound healing potentiallnt. J. Pharm. Sci. Rev. Res., 2013; 21(1), 318-324.

9. Terra RM, Guimaraes JA, Verli H. Structural and functional behavior of biologically active monomeric melittin.J Mol Graph Model. 2007; 25(6): 767-72.

10. Lee WR, Pak SC, Park KK. The Protective Effect of Bee Venom on Fibrosis Causing Inflammatory Diseases Toxins (Basel). 2015; 7(11): 4758-4772.

11. Han SM, Park KK, Nicholls YM, Macfarlane N, Duncan G Effects of honeybee (Apismellifera) venom on keratinocyte migration in vitro. Pharmacogn Mag. 2013; 9(35):220-6. doi: 10.4103/0973-1296.11327).

12. Grange PA, Raingeaud J, Calvez V, Dupin N.Nicotinamide inhibits Propionibacterium acnes-induced IL-8 production in keratinocytes through the NF-kappaB and MAPK pathways. J Dermatol Sci. 2009; 56(2):106-12. doi: 10.1016/j. jdermsci.2009.08.001. Epub 2009 Sep1.

13. Leandro LF, Mendes CA, Casemiro LA, Vinholis $A H$, Cunha WR, de Almeida R, Martins $\mathrm{CH}$.Antimicrobial activity of apitoxin, melittin and phospholipase $\mathrm{A} 2$ of honey bee (Apismellifera) venom against oral pathogens. An Acad Bras Cienc. 2015; 87(1):147-55.

14. Schumacher MJ, Tveten MS, Egen NB.Rate and quantity of delivery of venom from honeybee stings. J Allergy Clin Immunol. 1994; 93(5):831-5.

15. Elina, R.; Gabriel, M.; Jose, G.; Aldo, C; and Cristina, B. Bovine and rabbit models for the study of a Staphylococcus aureus a virulent mutant strain, RC122. The Canadian Journal of Veterinary Research; 2002; 66(4): 285.288.

16. Martin, D. R., Heffernan, H. M., \& Davies, H. G. Methicillin-resistant Staphylococcus aureus: an increasing threat in New Zealand hospitals. The New Zealand medical journal, 1989; 102(872), 367-369.

17. McGrath, L. J., Becker-Dreps, S., Pate, V., \& Brookhart, M. A. Trends in Antibiotic Treatment of Acute Otitis Media and Treatment Failure in Children, 2000-2011. PLoS One., 2013; 8(12), e81210. doi:10.1371/journal.pone.0081210.

18. Filius, P. M. G., \& Gyssens, I. C. Impact of increasing antimicrobial resistance on wound management. American journal of clinical dermatology, 2002; 3(1), 1-7.

19. Hwang, A. Y., \& Gums, J. G. The emergence and evolution of antimicrobial resistance: Impact on a global scale. Bioorganic \& medicinal chemistry, 2016; 24(24), 6440-6445.

20. Kam, K. M., Luey, K. Y., Fung, S. M., Yiu, P. P Harden, T. J., \& Cheung, M. M. Emergence of multiple-antibiotic-resistant Streptococcus pneumonia in Hong Kong. Antimicrobial agents and chemotherapy, 1995; 39(12), 2667-2670.

21. Alia, O., Laila, M., \& Antonious, A. Antimicrobial effect of melittin isolated from Syrian honeybee (Apis mellifera) venom and its wound healing potential. Int J Pharm Sci Rev Res, 2013; 21, 318-324.

22. Boutrin, M.-C., Foster, H., \& Pentreath, V. The effects of bee (Apis mellifera) venom phospholipase A2 on Trypanosoma brucei brucei and enterobacteria. Experimental Parasitology, 2008; 119(2): 246-251.

23. Perumal Samy, R., Gopalakrishnakone, P., Thwin, M., Chow, T., Bow, H., Yap, E., \& Thong, T. Antibacterial activity of snake, scorpion and bee venoms: a comparison with purified venom phospholipase A2 enzymes. J Appl Microbiol, 2007; 102(3): 650-659.

24. Alqutub, A. N., Masoodi, I., Alsayari, K., \& Alomair A. Bee sting therapy-induced hepatotoxicity: A case report. World journal of hepatology, 2011; 3(10): 268.

25. Cherniack, E. P. Bugs as drugs, Part 1: Insects: the" new" alternative medicine for the 21st century. Altern Med Rev., 2010; 15(2): 124-135.

26. Leandro, L. F., Mendes, C. A., Casemiro, L. A., Vinholis, A. H., Cunha, W. R., Almeida, R. d and Martins, C. H. Antimicrobial activity of apitoxin, melittin and phospholipase $A 2$ of honey bee (Apis mellifera) venom against oral pathogens. Anais da Academia Brasileira de Ciências, 2015; 87(1): 147-155. 
27. Kim, S.-T., Hwang, J.-Y., Sung, M.-S., Je, S.-Y., Bae, D.-R., Han, S.-M .and Lee, S.-H. The Minimum Inhibitory Concentration (MIC) of bee venom against bacteria isolated from pigs and chickens. Korean J Vet Serv, 2006; 29(1): 19-26.

28. Iyer, S., \& Jones, D. H. Community-acquired methicillin-resistant Staphylococcus aureus skin infection: a retrospective analysis of clinical presentation and treatment of a local outbreak. Journal of the American Academy of Dermatology, 2004; 50(6): 854-858.

29. Malachowa, N., Kobayashi, S. D., Porter, A R., Braughton, K. R., Scott, D. P., Gardner, D. J., Missiakas, D. M., Schneewind, O., \& DeLeo, F. R. Contribution of Staphylococcus aureus coagulases and clumping factor A to abscess formation in a rabbit model of skin and soft tissue infection. PLoS One, 2016; 11(6): e0158293.

30. Meulemans, L., Hermans, K., Duchateau, L., \& Haesebrouck, F. High and low virulence Staphylococcus aureus strains in a rabbit skin infection model. Veterinary Microbiology, 2007; 125(3-4): 333-340.

31. Bogdanov, S., \& Commission, H. m. o.t. I. H. Bee product science. 2011; www. beehexagon. net. 2008.

32. Oršoliæ, N. Bee venom in cancer therapy. Cancer and Metastasis Reviews, 2012; 31(1-2): 173-194.

33. Pandey, B. K., Ahmad, A., Asthana, N., Azmi, S., Srivastava, R. M., Srivastava, S., Verma, R., Vishwakarma, A. L., \& Ghosh, J. K. Cell-selective lysis by novel analogues of melittin against human red blood cells and Escherichia coli. Biochemistry, 2010; 49(36): 7920-7929.
34. Nevalainen, T. J., Graham, G. G., \& Scott, K. F. Antibacterial actions of secreted phospholipasesA 2. Review. Biochimica et Biophysica Acta (BBA)-Molecular and Cell Biology of Lipids, 2008; 1781(1): 1-9.

35. Giacometti, A., Cirioni, O., Kamysz, W., D’Amato, G., Silvestri, C., Del Prete, M. S., Lukasiak, J., \& Scalise, G. In vitro activity and killing effect of the synthetic hybrid cecropin A-melittin peptide CA (1-7) M (2-9) NH2 on methicillin-resistant nosocomial isolates of Staphylococcus aureus and interactions with clinically used antibiotics. Diagnostic Microbiology and Infectious Disease, 2004; 49(3): 197-200.

36. Han, S., Yeo, J., Baek, H., Lin, S.-M., Meyer, S., \& Molan, P. Postantibiotic effect of purified melittin from honeybee (Apis mellifera) venom against Escherichia coli and Staphylococcus aureus. Journal of Asian natural productsresearch, 2009; 11(9): 796-804.

37. Toke, O. Antimicrobial peptides: new candidates in the fight against bacterial infections. Peptide Science: Original Research on Biomolecules, 2005; 80(6): 717-735.

38. Choi, J. H., Jang, A. Y., Lin, S., Lim S., Kim, D., Park, K., Han, S. M., Yeo, J. H., \& Seo, H. S. Melittin, a honeybee venom derived antimicrobial peptide, may target methicillin resistant Staphylococcus aureus. Molecular medicine reports, 2015; 12(5): 6483-6490.

39. Giuliani, A., Pirri, G., Bozzi, A., Di Giulio, A., Aschi, M., \& Rinaldi, A. Antimicrobial peptides: natural templates for synthetic membraneactive compounds. Cellular and Molecular Life Sciences, 2008; 65(16): 2450-2460. 